Original Research Paper

\title{
Spread Foundations on Rigid Inclusions Subjected to Complex Loading: Comparison of 3D Numerical and Simplified Analytical Modelling
}

\author{
${ }^{1}$ Daniel Dias and ${ }^{2}$ Bruno Simon \\ ${ }^{1}$ Grenoble Alpes University, 3SR Laboratory, Grenoble, France \\ ${ }^{2}$ TERRASOL, Paris, France
}

\author{
Article history \\ Received: 07-08-2015 \\ Revised: 03-09-2015 \\ Accepted: 04-09-2015 \\ Corresponding Author: \\ Daniel Dias \\ Grenoble Alpes University, \\ Laboratoire Sols, Solides, \\ Structures, Risques (3SR), BP \\ 53-Domaine Universitaire 38041 \\ Grenoble Cedex 9, France \\ Tel: +33456520994 \\ Email: daniel.dias@ujf-grenoble.fr
}

\begin{abstract}
This paper relates results of a large number of 3D numerical models of a single spread footing over a soil reinforced by four rigid inclusions and submitted to a large set of complex loading. This numerical study using the FLAC 3D software was done under funding of the ASIRI research project in an aim to support appropriate guidelines for design of such foundations. From these models a database of displacements and stresses in any 4 piles was built. An alternate simplified approach is also described using tools commonly used for pile foundation design. All results are found to be in fair agreement. This gives credit to the use of the simplified approach for design of this kind of foundation.
\end{abstract}

Keywords: Spread Foundation, Rigid Inclusion, 3D Numerical Modelling, Analytical Modelling

\section{Introduction}

Soil reinforcement by rigid inclusions has proved to be an efficient foundation solution for ground slabs of industrial facilities. Slabs submitted to uniform loading can be designed from the results of an axisymmetric numerical model of the elementary reinforcement cell including the tributary slab, the granular layer, the inclusions and the soil volume around (Cuira and Simon, 2009). Data gathered by the French ASIRI national research project (Girout et al., 2014; Jenck et al., 2005; 2007; Nunez et al., 2013; Okyay et al., 2014) have demonstrated that such simple models are reliable and easy to use providing that some basic requirements are fulfilled (ASIRI, 2012; Briançon and Dias, 2015).

Industrial or commercial facilities often have locally concentrated loads, from their columns or inner bearing walls. They are usually founded using a compound foundation system comprising a concrete spread footing, a granular layer acting as a load transfer platform and a limited number of rigid inclusions below. Such conditions preclude use of axisymmetric models and require truly $3 \mathrm{D}$ models. Since loading of these individual foundations involves vertical as well as horizontal loading, with some possible eccentricity, such 3D models cannot be reduced by symmetry considerations. They remain a difficult engineering task and require strong computational effort. Some simplified numerical models are therefore required so that design of this appealing foundation solution remain a task within reach of these quite common projects.

An extensive numerical study of a single spread footing over a soil reinforced by four rigid inclusions and submitted to a large set of complex loading has been carried out within the framework at the ASIRI research project. The FLAC 3D finite difference software was used to run these models and establish a database of displacements and stresses in any 4 inclusions. An alternate simplified approach was also developed using tools commonly used for pile foundation design.

This paper describes both the numerical Flac 3D study and the simplified approach and compares both results.

\section{Investigated Case and Associated Numerical Model}

The study was led for one usual case of a spread footing lying over soft soil which is reinforced by four rigid inclusions arranged in a square grid, as illustrated by Fig. 1.

The concrete square spread footing is $2.8 \mathrm{~m}$ long and $0.5 \mathrm{~m}$ thick; it lies on a $0.5 \mathrm{~m}$ thick granular layer (granular pad). The soft soil layer has a total thickness $6.5 \mathrm{~m}$ below the granular pad base; it rests on top of a rigid stratum.

The inclusion diameter is $0.34 \mathrm{~m}$ and the pile spacing is $1.5 \mathrm{~m}$. 


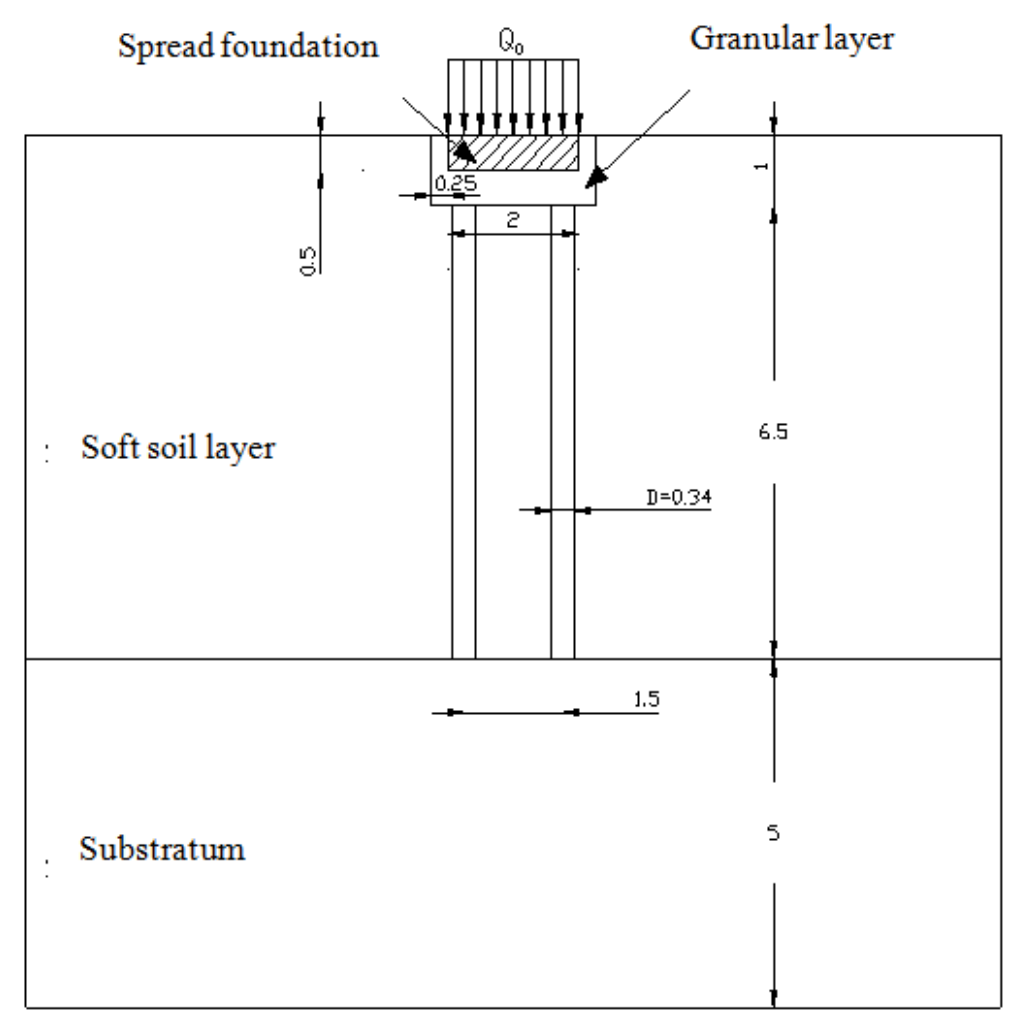

Fig. 1. Geometrical configuration studied

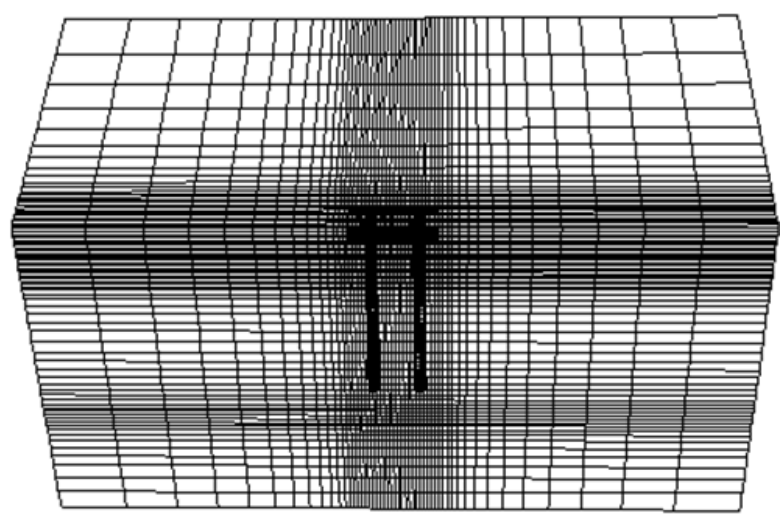

Fig. 2. View of the three dimensional numerical model of soft ground improved by piles

Due to symmetry condition, only half of the problem is modelled when combined loadings are used (inclined) and a quarter if only vertical loadings are applied. The calculations are performed using the finite difference software Flac3D (Itasca, 2002). The numerical model for the half model includes about 75,000 zones and 90,000 grid points.

Figure 2 is a top view of the numerical model. The model length in the horizontal direction is seven times the pile spacing $(14 \mathrm{~m})$. The piles are stopped at the bearing stratum upper face. Interfaces are considered in this model: Relative displacementsare possible between the piles and the soft soil as well as between the granular mat and the footing.

The foundation pad was constructed in several phases:

- Excavate the zone for the granular mat and for the footing

- Setup of the piles in one phase: The pile installation is not taken into account

- Installation of the granular mat

- Setup of the footing

- Initialization of the displacements

The model equilibrium is reached at each step. The time dependant behaviour of the system is not investigated here, the calculations are performed in drained conditions.

\section{Ground Characteristics and Behaviour Modelling}

This part presents the geotechnical properties assigned for each part of the system (soft ground, granular mat, footing and piles) and the constitutive models used for the calculations.

\section{Soft Soil}

Soft soil layers which are reinforced by a grid of piles are typically clay and/or silt deposits. 
Table 1. Cam-Clay model parameters for the soft soil layer

\begin{tabular}{llllllll}
\hline Parameter & $\lambda$ & $\kappa$ & $\mathrm{M}$ & $\mathrm{e}_{\lambda}$ & $\mathrm{v}$ & $\gamma\left(\mathrm{kN} / \mathrm{m}^{3}\right)$ & $\mathrm{K}_{0}$ \\
\hline Value & 0.13 & 0.048 & 1.2 & Variable 3.4 to 3.8 & 0.35 & 17 & 0.8
\end{tabular}

Note: $\lambda=$ slope of the normal consolidation line; $\kappa=$ slope of the swelling line; $\mathrm{M}=$ frictional constant; $\mathrm{e}_{\lambda}=$ void ratio at normal consolidation for $\mathrm{p}=1 \mathrm{kPa} ; \mathrm{v}=$ Poisson's ratio; $\gamma=$ unit weight and $K_{0}=$ horizontal earth pressure coefficient at rest

Table 2. CJS2 Model Material Parameters for the granular material

\begin{tabular}{llllllllll}
\hline Parameter & $\mathrm{G}_{0}(\mathrm{MPa})$ & $\mathrm{K}_{0 \mathrm{e}}(\mathrm{MPa})$ & $\mathrm{n}$ & $\beta$ & $\mathrm{R}_{\mathrm{c}}$ & $\mathrm{A}\left(\mathrm{Pa}^{-1}\right)$ & $\mathrm{R}_{\mathrm{m}}$ & $\gamma$ & $\mathrm{K}_{0 \mathrm{p}}(\mathrm{MPa})$ \\
\hline Value & 5 & 13 & 0.6 & 0.27 & 0.001 & 0.35 & 0.35 & 0.9 & 50 \\
\hline
\end{tabular}

The Modified Cam Clay model (Roscoe and Burland, 1968 ) is widely used to simulate the behaviour of such deposits (Mestat et al., 2004): This model is used here.

The marine soft deposit of Muar in Malaysia was simulated using this constitutive model (Indraratna et al., 1992). The soft soil is lightly over consolidated, which is represented by an over-consolidation pressure equal to $\sigma_{\mathrm{v}}{ }^{\prime}+10 \mathrm{kPa}$, where $\sigma_{\mathrm{v}}{ }^{\prime}$ is the effective vertical stress. The parameters used in the modelling are given in Table 1.

\section{Granular Material}

The embankment material is generally gravel or coarse soils. Its behaviour is highly nonlinear (Paute et al., 1994). A two mechanism isotropic hardening elastoplastic model CJS2 has been used to simulate the granular material behaviour. The CJS2 model derives from the CJS model developed by Cambou and Jafari (1988) for cohesionless soils. The original model has two mechanisms, the compression mechanism having isotropic hardening and the deviatoric mechanism having two hardening mechanisms, one is isotropic and the other is deviatoric. The elastic part is nonlinear. The granular material described and tested by Fragaszy et al. (1992) is used in these calculations (Table 2). The corresponding friction angle for this granular material is equal to $35^{\circ}$.

\section{Inclusions and Footing}

The inclusions are reinforced concrete piles. They behave elastically and the elastic parameters are $\mathrm{E}=$ $20 \mathrm{GPa}$ and $v=0.2$. Same parameters have been applied to the concrete spread footing.

\section{Parametric Study}

Several loading cases have been studied. An uniform distributed load $\mathrm{q}$ is applied incrementally to the footing by $50 \mathrm{kPa}$ steps; load inclination $\theta$ to the vertical axis is taken $0,5,10,20,30$ and $40^{\circ}$ in turn.

In a preliminary stage, the same numerical model serves to simulate a few specific simple loading cases to help the calibration of some of the distinctive geotechnical parameters used by the simplified method, i.e., the Menard pressure meter modulus and the limiting values of shaft friction and point pressure. This included:
- Loading at the head of a single inclusion either axially or transversely, to get the corresponding load-pile displacement curves at head and tip

- Loading of the footing either vertically or horizontally with inclusions replaced by soil elements to get the corresponding load-displacement curve of the non reinforced case

\section{Numerical Results}

Figure 3 shows the displacement field for a pad foundation surcharge of $150 \mathrm{kPa}$ inclined at a $20^{\circ}$ angle. One can see that the pile at the left hand displaces more than the other one. Soil displacement is significant down to $1.5 \mathrm{~m}$ from the pile heads.

Even when the loading is purely vertical, the inclusions are submitted to a bending moment. For a loading of $150 \mathrm{kPa}$, this bending moment can reach $2.3 \mathrm{kNm}$ (Fig. 4).

The bending moment increases with the load inclination and reaches $16.5 \mathrm{kNm}$ in the front (left) inclusion when inclination is $20^{\circ}$. The rear (right) inclusion always bears a moment value inferior than the front inclusion. Difference between front and rear pile moments also increases with load inclination and reaches $7 \mathrm{kNm}$ in the last case.

For more inclined loading, failure can be observed in the numerical calculations. A loading of $100 \mathrm{kPa}$ is the maximum for $30^{\circ}$ and $75 \mathrm{kPa}$ for $40^{\circ}$.

\section{Simplified Analytical Method}

\section{Presentation}

The simplified analytical method for designing spread foundations over inclusion reinforced soils was described by Simon (2010). It consists of assimilating the reinforced soil volume with inclusions aligned along the footing at an equivalent homogeneous monolith, leading to a consecutive analysis of the following:

- The interaction between inclusions inside the reinforced volume, for the purpose of establishing the properties of this equivalent homogeneous monolith

- Then the interaction of this monolith with the exterior, unreinforced soil block 


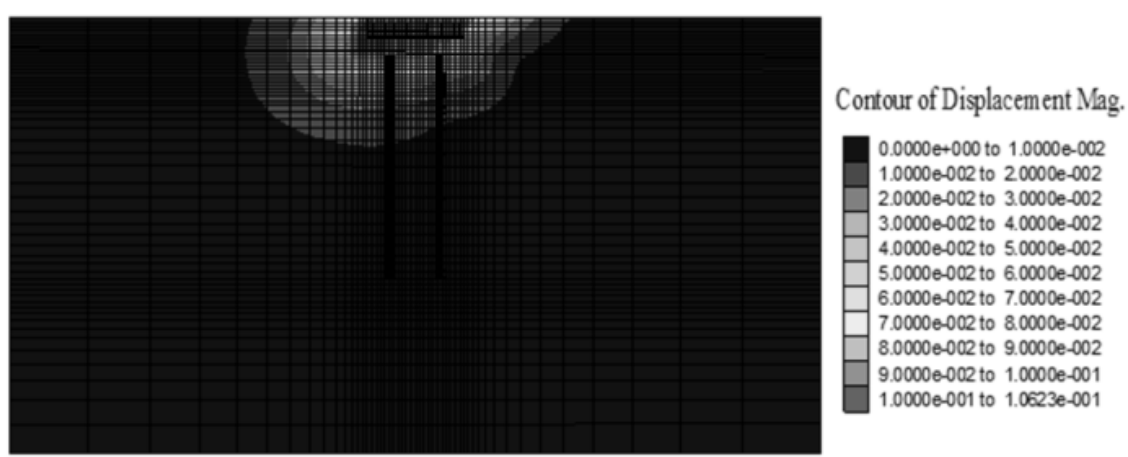

Fig. 3. Displacement field for a loading of $q=150 \mathrm{kPa}$ inclined at $\theta=20^{\circ}$

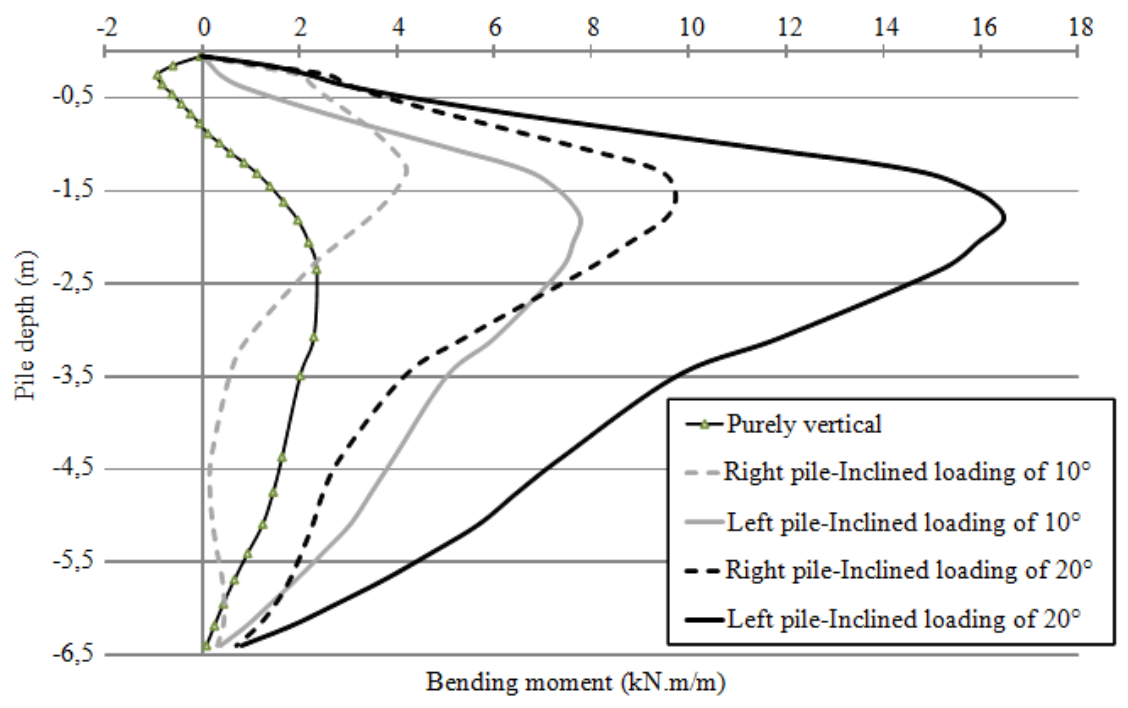

Fig. 4. Bending moment for different load inclinations $-\mathrm{q}=150 \mathrm{kPa}$

The monolith studied herein is the vertical axis prism circumscribed at the footing which includes the granular mat, the soft soil layer reinforced by inclusions and the upper part of the bearing layer.

\section{Under Vertical Loading}

This approach entails 3 successive steps which are carried out using ordinary tools for deep foundation design, i.e., study of an isolated pile or of a pile located at the centre of a reinforcement element mesh, under vertical loading, through use of transfer functions characterizing shaft friction and point pressure mobilization around the pile (Cuira and Simon, 2009). In the reinforcement mesh case, the analytical model is of a biphasic type (i.e., associating a pile domain and a soil domain) where interaction forces between both domains are expressed by the same transfer functions as an isolated pile, just replacing the absolute piledisplacement by the relative soil-pile displacement. The transfer functions given by Frank and Zhao (1982) are used; they depend solely on the Menard pressuremeter modulus $\mathrm{E}_{\mathrm{M}}$, the limiting shaft friction value $\mathrm{q}_{\mathrm{s}}$ (resp. point pressure $\mathrm{q}_{\mathrm{p}}$ ) for any given pile diameter and type (Bustamante and Frank, 1999).

Beforehand calculations considering the case of an axially loaded isolated inclusion demonstrated that values of Table 3 led to load-displacement curves at head and tip that agreed well with the numerically derived ones, using Flac 3D. Settlement of the soft soil is calculated using oedometric parameters derived from the values in Table 1.

\section{Step 1}

A study of the behaviour, under distributed vertical load, of a basic cell without any interaction with the external domain (i.e., case of a cell placed in the middle of a multiple network of identical cells) serves to establish the horizontal plane position underneath the inclusion tip where soil settlement is uniform (lower neutral plane). The average settlement derived between the upper cell face (below the footing) and this lower plane allows evaluating the apparent modulus of deformation $\mathrm{E}^{*}$ of the cell under vertical loading (Fig. 5). 


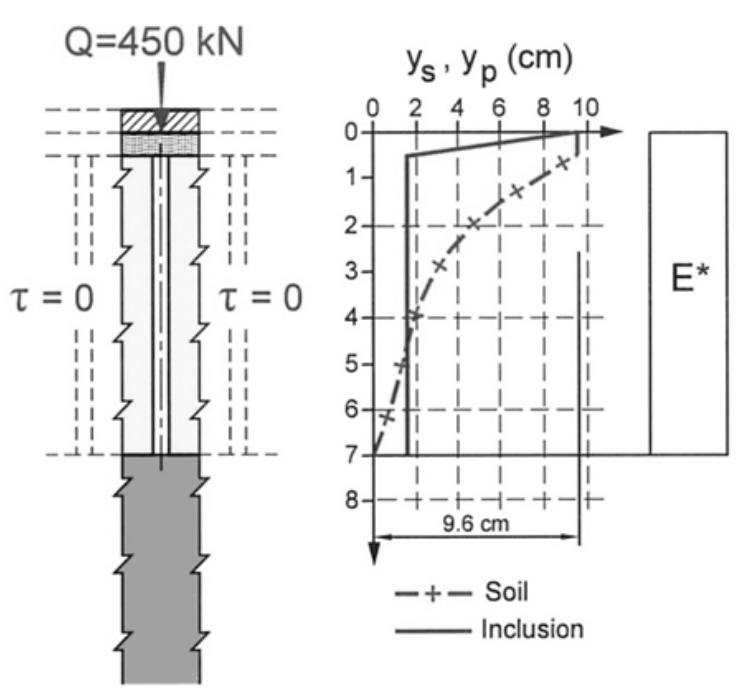

Fig. 5. Step 1 of the calculation according to the simplified method-Cell mesh area $1,5 \mathrm{~m}^{2}$, vertical load case $\mathrm{q}=$ $200 \mathrm{kPa}$

Table 3. Soil parameters for the simplified method

\begin{tabular}{llll}
\hline & $\mathrm{E}_{\mathrm{M}}(\mathrm{MPa})$ & $\mathrm{q}_{\mathrm{s}}(\mathrm{kPa})$ & $\mathrm{q}_{\mathrm{p}}(\mathrm{MPa})$ \\
\hline Soft soil & 2.5 & 30 & - \\
Substratum bearing & 8.0 & - & 7.2 \\
\hline
\end{tabular}

\section{Step 2}

A study of the vertical monolith with modulus $\mathrm{E}^{*}$ assimilated to an isolated pile interacting with the exterior (non-reinforced) soil domain, exposed to vertical force $\mathrm{Q}$, determines the profile $\mathrm{y}_{\mathrm{s}}(\mathrm{z})$ of the average monolith settlement, accounting for the shaft friction mobilization on the monolith perimeter. The settlement recorded at the head $\mathrm{y}_{\mathrm{s}}$ remains lower than the settlement of the cell studied during Step 1, as a result of the load diffusion by means of shaft friction towards the surrounding soil block (Fig. 6).

The friction taken into account at the monolith edge is the soil friction; its limiting value may be assimilated with the undrained cohesion $\mathrm{c}_{\mathrm{u}}$ of the soft soil (estimated around $60 \mathrm{kPa}$ in this specific case).

This monolith calculation also proved to be able to predict with sufficient accuracy the settlement of the footing lying on an unreinforced soil, as derived numerically using Flac 3D.

\section{Step 3}

The load-displacement curve of an inclusion assumed to be isolated (including the granular pad prism displaying the same cross-section as inclusion) in a soil block subjected to an imposed settlement profile as calculated in step 2 makes it possible to establish the load value to apply at the head of this column in order to obtain the same settlement as previously calculated at top of the model. This load value then determines the distribution of axial forces $Q_{p}(\mathrm{z})$ in the actual inclusion (Fig. 7).
The simplified method incorporates neither the Mohr Coulomb failure criterion of the granular layer material nor a full constitutive law for negative skin friction. Therefore to validate the simplified model consistency, it is necessary to verify that the stress found at the inclusion head is compatible with the granular layer shear strength characteristics and also that the friction mobilized above the neutral plane is compatible with the limiting value of negative skin friction Ktan $\delta . \sigma_{\mathrm{v}}$ ' (ASIRI, 2012).

\section{Comparison between the Simplified Method and the Flac 3D Numerical Study}

The comparison of results concerning the inclusion axial load or the pile and average soil settlement has shown fair agreement between the numerical Flac 3D calculation and the simplified method. This is illustrated by Fig. 8 for the vertical load case $\mathrm{q}=200 \mathrm{kPa}$.

\section{Under Transverse Loading}

The simplified method is composed of two successive additional steps (Simon, 2010). Both make use of an ordinary tool for pile foundation design, i.e., study of an isolated pile bearing on elastic-plastic springs $\left(\mathrm{p}=\mathrm{p}(\mathrm{y})<\mathrm{p}_{\text {lim }}\right)$.and subjected to transverse loading, as depicted by force $\mathrm{T}$ and bending moment $\mathrm{M}$ applied at the head and/or a displacement imposed on the surrounding soil $\mathrm{g}(\mathrm{z})$.

The $p-y$ curve is calculated from the assumed $E_{M}$ Menard pressuremeter modulus, following standard expressions for sustained loading (Frank, 1999).

Beforehand calculations by this approach of a horizontal loading at the head of a single inclusion establish that $E_{M}$ value for soft soil given in Table 3 (together with a limit pressure value $\mathrm{p}_{1}=0.25 \mathrm{MPa}$ ) leads to a load-displacement curve that agreed well with the numerically derived ones, using Flac 3D.

\section{Step 4}

The monolith with an equivalent modulus of $\mathrm{E}^{*}$ (as established during step 1) is assimilated with a transversely-loaded pile interacting with the external unreinforced soil block via elastic-plastic springs The calculation establishes a lateral displacement profile $\mathrm{g}(\mathrm{z})$ for the monolith under action of the horizontal force $\mathrm{T}$ and bending moment $\mathrm{M}$ loading applied to the footing (Fig. 9).

The limited monolith length-to-width ratio and its orthotropic nature however necessitate taking shear deformations of the pile into account, in addition to bending deformations. The simple model of a slender beam, commonly used for piles, tends to be inappropriate. These shear deformations are controlled by the $G^{*} A^{\prime}$ factor (with $G^{*}$ being the equivalent shear modulus of the monolith and $\mathrm{A}^{\prime}$ the reduced shear cross-section). 

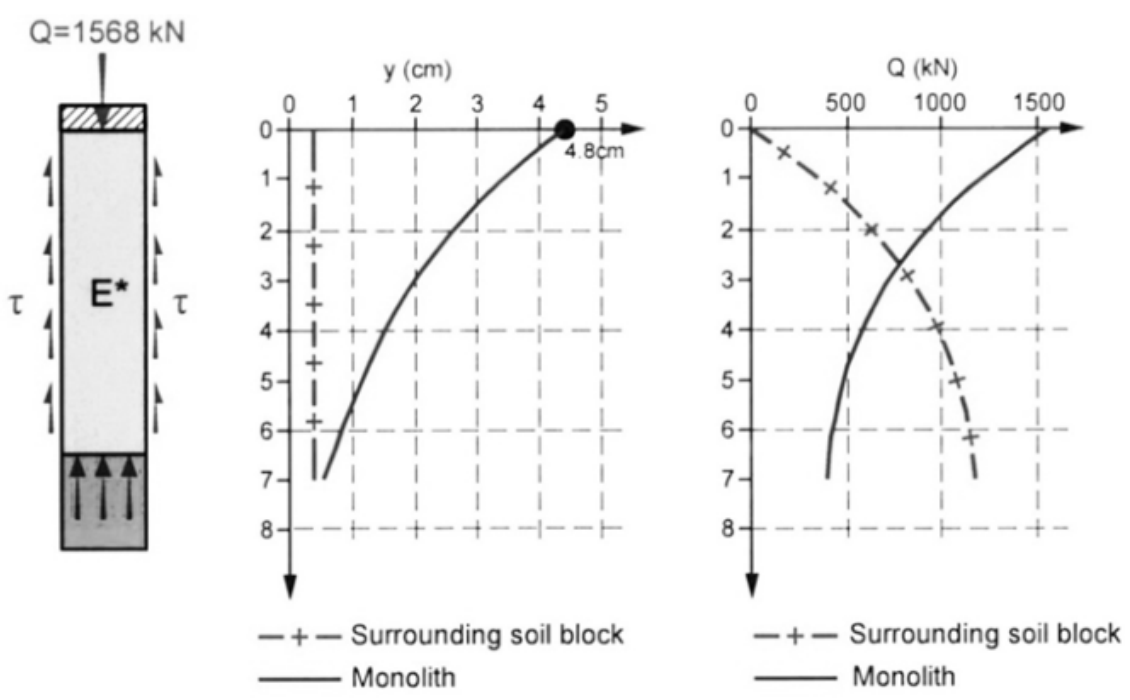

Fig. 6. Step 2 of the calculation according to the simplified method - Monolith cross-section area $2.8 \mathrm{~m}^{2}$, vertical load case $\mathrm{q}=200 \mathrm{kPa}$
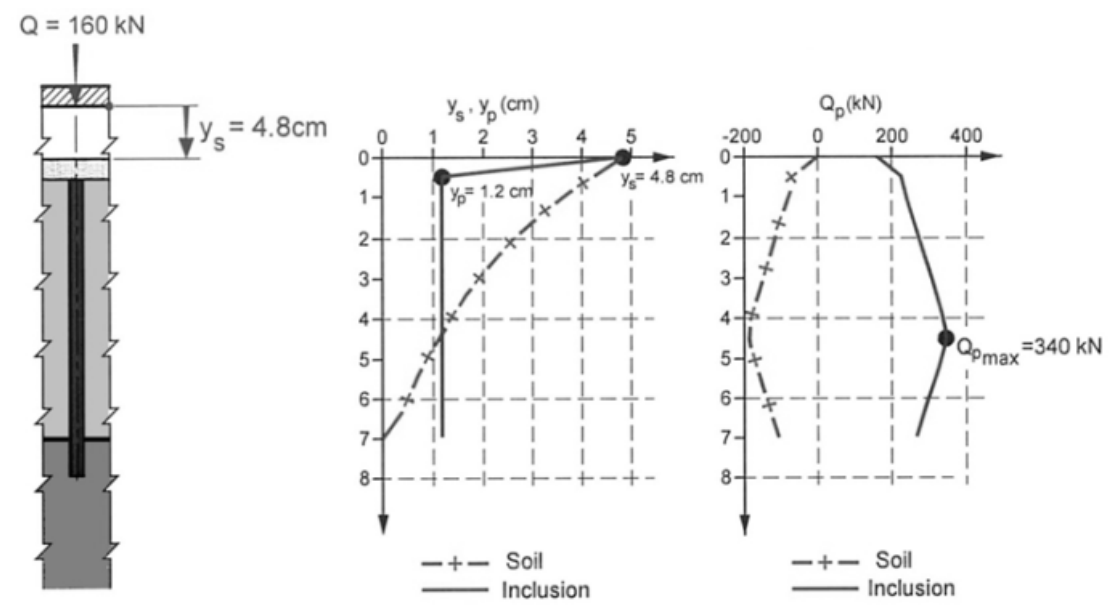

Fig. 7. Step 3 of the calculation according to the simplified method-Inclusion diameter $0.34 \mathrm{~m}$, vertical load case $\mathrm{q}=200 \mathrm{kPa}$

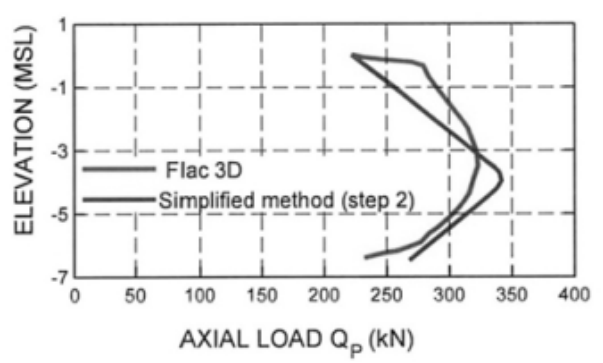

(a)

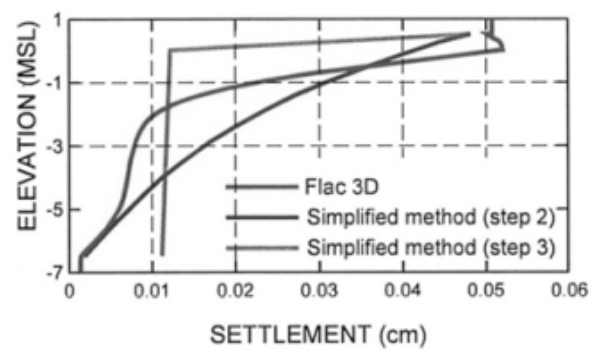

(b)

Fig. 8. Comparison between simplified analytical method and numerical Flac 3D-Vertical load case $\mathrm{q}=200 \mathrm{kPa}$. (a) Axial load in inclusions (b) Soil and pile settlement

The equivalent shear modulus $\mathrm{G}^{*}$ may be assimilated with the shear modulus Gsol of the soil on its own (since the contribution of inclusions to shear strength in effect remains negligible compared to that of the soil). Bending deformations depend from the factor $\mathrm{E}^{*} \mathrm{I}$ (where $\mathrm{E}^{*}$ is the monolith's apparent equivalent modulus (established during step 1) and I the monolith flexural rigidity). 
A monolith calculation of the same kind also enabled to predict with sufficient accuracy the horizontal displacement of the footing lying on an unreinforced soil, as derived numerically using Flac 3D. In that case, $\mathrm{G}^{*}$ and $\mathrm{E}^{*}$ of the monolith were assimilated to Gsol and Esol.

\section{Step 5}

A subgrade reaction pile model, limited to the inclusion alone and assumed subjected to the previous displacement field $g(z)$, enables to calculate the shear force and bending moment distributions in the inclusion for any given set of boundary conditions at the inclusion head and tip.

A horizontal force can develop at any inclusion head by friction exerted by the granular pad. A limiting value of this force can thus be found by considering the concomitant axial load in the same case. One can nevertheless observe that this force cannot induce a displacement of the inclusion head that exceeds displacement of the surrounding soil. Therefore a quite conservative assumption consists of selecting for the boundary condition $\mathrm{T}_{\mathrm{p}}(0)$ a value that "reduces" inclusion head displacement to that of the surrounding soil. This is illustrated in Fig. 10 for the same example as already introduced.

Axial forces in the inclusions depend on the cell position with respect to the axis of rotation. The footing rotation $\omega$ (as calculated during Step 4) actually determines settlement along the axis of the cell placed a distance $\mathrm{d}$ from the axis of rotation, as follows: $y p=\omega . d$.

The associated axial forces in the inclusion placed at the centre of this cell can then be estimated by assimilating them with the axial forces found under a uniform vertical loading of the cell that yields the same settlement. This step is performed by means of a specific calculation linking Steps 2 and 3.

The values of the corresponding axial force, shear force and bending moment obtained according to the vertical and transverse load cases must be combined in order to verify stresses in the inclusions.

\section{Comparison between the Simplified Method and the Flac 3D Numerical Study}

Figure 11 plots the different inclusion displacement fields which are obtained when the shear force boundary condition $T_{p}(0)$ value is varied between 0 and the one giving equal soil and inclusion displacements at head. They can also be compared to the front inclusion displacement field as calculated by Flac 3D. This latter one reveals a strong similarity with the simplified method curve for $\mathrm{T}_{\mathrm{p}}(0)=0$.

The same holds true for the bending moment (or the shear force) profiles shown on Fig. 12a or b.
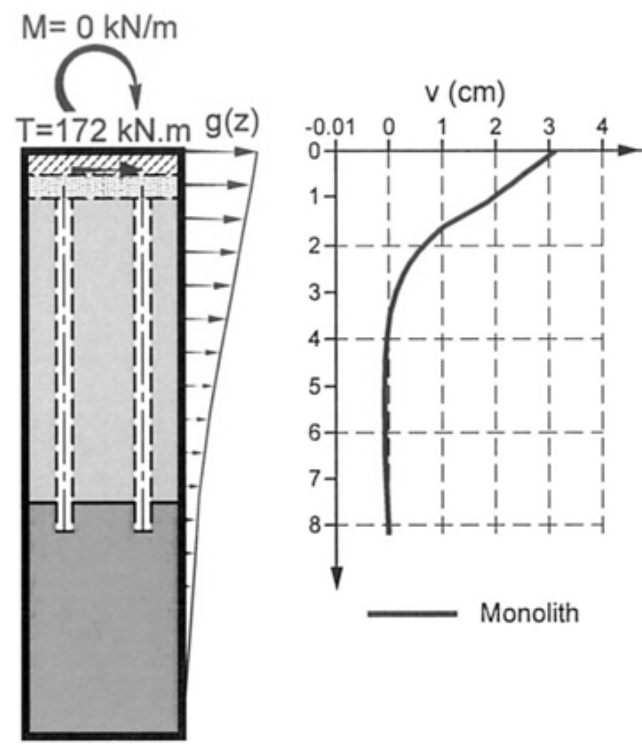

Fig. 9. Step 4 of the calculation, according to the simplified method-Monolith cross-section area $2.8 \mathrm{~m}^{2}$, inclined load case $\mathrm{q}=200 \mathrm{kPa}, \theta=10^{\circ}$
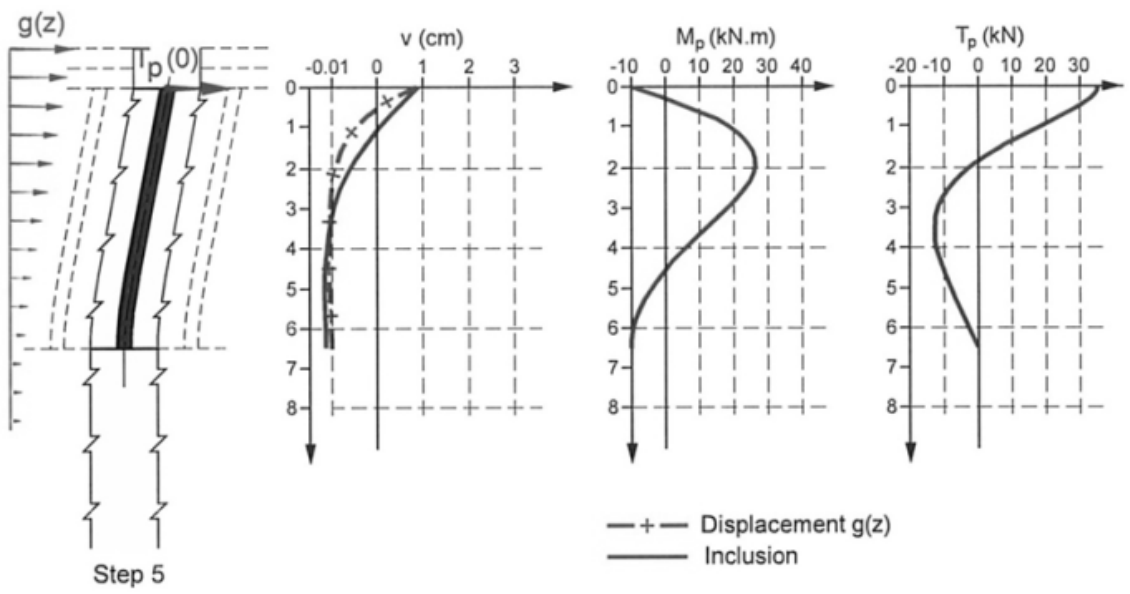

Fig. 10. Step 5 of the calculation, according to the simplified method 


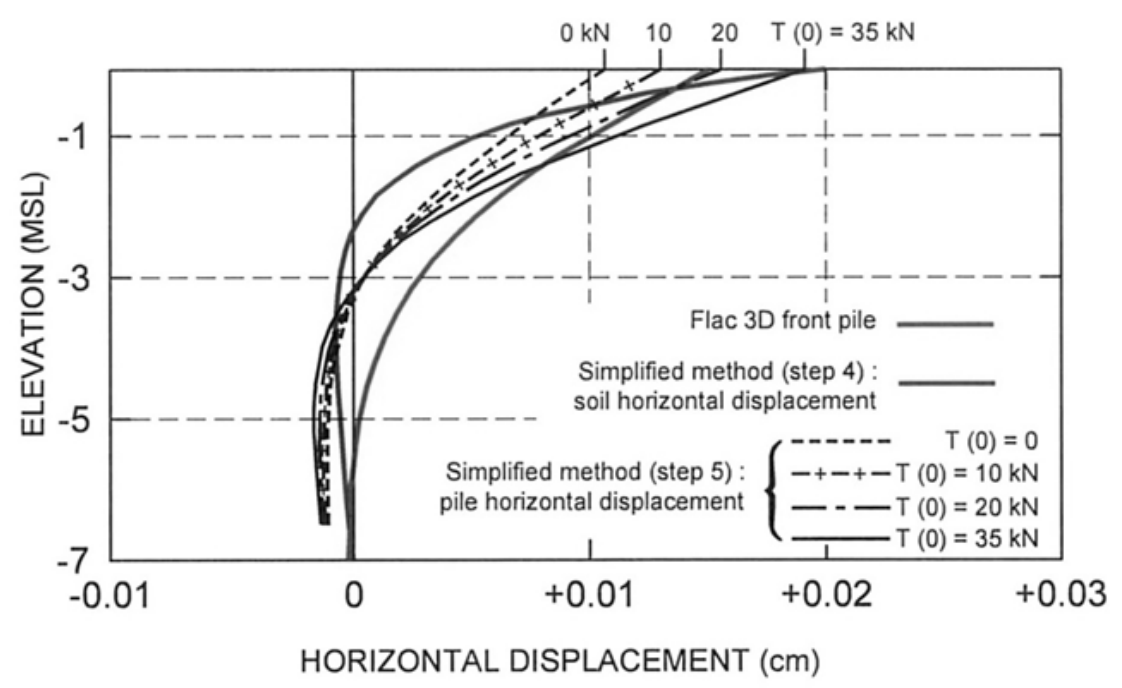

Fig. 11. Comparison of the horizontal displacement profile calculated by Flac 3D model and the simplified method for a range of shear force boundary conditions $\mathrm{T}(0)$ at the inclusion head-Inclined load case $\mathrm{q}=200 \mathrm{kPa}, \theta=10^{\circ}$
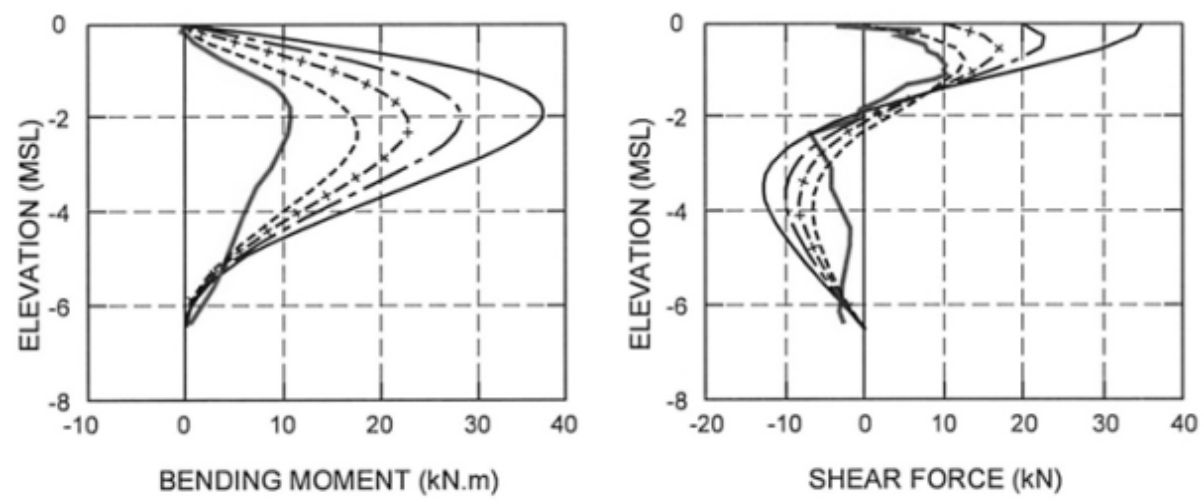

Flac 3D front pile

Simplified method (step 5) $\left\{\begin{array}{l}T(0)=0 \\ T(0)=10 \mathrm{kN}-+-+- \\ T(0)=20 \mathrm{kN}--- \\ T(0)=35 \mathrm{kN}-\end{array}\right.$

(a)

(b)

Fig. 12. Comparison between Flac 3D results and simplified method results obtained with a range of shear force boundary conditions $\mathrm{T}(0)$ at inclusion head-Inclined load case $\mathrm{q}=200 \mathrm{kPa} \theta=10^{\circ}$ (a) Bending moment (b) Shear force

For this particular case, best agreement is found assuming in step 5 of the simplified method that no friction develops at the inclusion head thus giving $\mathrm{T}(0)=$ 0 . This suggests that the granular pad shear strength was fully mobilized under the vertical load component, leaving no residual friction capacity in reaction to any soil-pile horizontal displacement; this could also be stated: "The vertical axis remains a principal stress direction in the vicinity of the inclusion head during transverse loading".

Further evaluation of the simplified method is planned using the results of an on-going dedicated centrifuge testing program also funded by the ASIRI project.

\section{Conclusion}

Flac 3D numerical modelling of a single spread footing on soft soil which is reinforced by four rigid inclusions has been carried out for a comprehensive range of loading conditions as for load intensity or inclination. Despite its simplicity, this foundation solution proves a heavy modelling task in order to maintain a proper balance between calculation practicability and solution accuracy. Results of these calculations were intended to serve as a reference case to elaborate guidelines for the design of foundations of this kind.

In that goal the Flac numerical model was also used to establish the load-displacement curves of the different 
structural elements (footing, inclusions) which are combined in this foundation solution, when vertical or horizontal loading is applied directly at the head of this element, left isolated in the same soil body.

This proved useful to calibrate in a step by step approach, a simplified method of designing the compound foundation obtained by associating a spread footing, a granular pad and a few inclusions. The simplified method which was evaluated in this way makes use of tools commonly used for pile foundation design under vertical or transverse loading. The comparison between the Flac 3D numerical results and those of the simplified method has so far shown quite fair agreement in all the investigated cases.

\section{Acknowledgement}

The authors wish to acknowledge the French national project (ASIRI) for funding this research. This work was made possible thanks to the financial support of DRAST and RGCU.

\section{Author's Contributions}

Daniel Dias: 3D calculations, write the paper and relecture.

Bruno Simon: Analytical modelling, write the paper and relecture.

\section{Ethics}

This article is original and contains unpublished material. The corresponding author confirms that all of the other authors have read and approved the manuscript and no ethical issues involved.

\section{References}

ASIRI, 2012. Recommendations for design, construction and control of foundation over soils reinforced by inclusions. Presses des Ponts, Paris.

Briançon, L. and D. Dias, 2015. Monitoring and numerical investigation of a rigid inclusionsreinforced industrial building. Canadian Geotechnical J., DOI: 10.1139/cgj-2014-0262

Bustamante, M. and R. Frank, 1999. Current French design practice for axially loaded pipes. National Academy of Sciences.

Cambou, B. and K. Jafari, 1988. Modele de comportement des sols non coherents. Revue Française de Géotechnique, 44: 43-55.

Cuira, F. and B. Simon, 2009. Deux outils simples pour traiter des interactions complexes d'un massif renforcé par inclusions rigides. Proceedings of the 17th International Conference on Soil Mechanics and Geotechnical Engineering, (MGE' 09), Alexandria, pp: 1163-1166.

DOI: $10.3233 / 978-1-60750-031-5-1163$
Fragaszy, R.J., J. Su, H. Siddigi and C.J. Ho, 1992. Modeling strength of sandy gravel. J. Geotechnical Eng., 118: 920-935.

DOI: 10.1061/(ASCE)0733-9410(1992)118:6(920)

Frank, R., 1999. Calcul Des Fondations Superficielles et Profondes. 1st Edn., Techniques de l'Ingénieur, Paris, ISBN-10: 2859783113, pp: 141.

Frank, R. and S.R. Zhao, 1982. Estimation par les paramètres pressiométriques de l'enfoncement sous charge axiale de pieux forés dans des sols fins. Bull. Liaison P. et Ch., 119: 17-24.

Girout, R., M. Blanc, D. Dias and L. Thorel, 2014. Numerical analysis of a geosynthetic-reinforced piled load transfer platform-Validation on centrifuge test. Geotext. Geomembr., 42: 525-539. DOI: 10.1016/j.geotexmem.2014.07.012

Indraratna, B., A.S. Balasubramaniam and S. Balachandran, 1992. Performance of test embankment constructed to failure on soft marine clay. J. Geotechnical Eng., 118: 12-33. DOI: 10.1061/(ASCE)0733-9410(1992)118:1(12)

Itasca, 2002. Flac3D-User's Guide.

Jenck, O., D. Dias and R. Kastner, 2005. Soft ground improvement by vertical rigid piles two-dimensional physical modelling and comparison with current design methods. Soils Foundat., 45: 15-31. DOI: $10.3208 /$ sandf.45.15

Jenck, O., D. Dias and R. Kastner, 2007. Twodimensional physical and numerical modeling of a pile-supported earth platform over soft soil. J. Geotechnical Geoenviron. Eng., 133: 295-305. DOI: 10.1061/(ASCE)1090-0241(2007)133:3(295))

Mestat, P., A. Dhouib, J.P. Magnan and Y. Canepa, 2004. Résultats de L'exercice De Prévision Des Tassements D'un Remblai Construit Sur Des Colonnes Ballastées. In: Presses de l'Ecole Nationale des Ponts et Chaussées, Magnan, J.P. (Ed.), Paris, pp: 1-13.

Nunez, M., L. Briançon and D. Dias, 2013. Analyses of a pile-supported embankment over soft clay: Fullscale experiment, analytical and numerical approaches. Eng. Geo., 153: 53-67. DOI: $10.1016 /$ j.enggeo.2012.11.006

Okyay, U., D. Dias, L. Thorel and G. Rault, 2014. Centrifuge modeling of a pile-supported granular earth-platform. J. Geotech. Geoenviron. Eng. DOI: 10.1061/(ASCE)GT.1943-5606.0001004

Paute, J.L., P. Hornych and J.P. Benaben, 1994. Comportement mecanique des graves non traitees. Bulletin de Liaison des Ponts et Chaussées, 190: 27-38.

Roscoe, K.H. and J.B. Burland, 1968. On the Generalized Stress Strain Behaviour of Wet Clay. In: Engineering Plasticity, J. Heyman and F.A. Leckie (Eds.), Cambridge University Press, Cambridge, England, pp: 535-609.

Simon, B., 2010. Une méthode simplifiée pour le calcul des semelles sur sol renforcé par inclusions rigides. JNGG, 1: 529-536. 